\title{
Nesting biology of Centris (Centris) aenea Lepeletier (Hymenoptera, Apidae, Centridini)
}

\author{
Cândida Maria Lima Aguiar ${ }^{1}$ \& Maria Cristina Gaglianone ${ }^{2}$
}

\author{
1 Departamento de Ciências Biológicas, Universidade Estadual de Feira de Santana. Rodovia BR 116, km 3, 44031-460 Feira \\ de Santana, Bahia, Brasil. E-mail: claguiar@uefs.br \\ 2 Laboratório de Ciências Ambientais, CBB, Universidade Estadual do Norte Fluminense. Avenida Alberto Lamego 2000, \\ 28013-600 Campos dos Goytacazes, Rio de Janeiro, Brasil. E-mail: mcrisgag@uenf.br
}

\begin{abstract}
Nesting activity of Centris aenea Lepeletier, 1841 was studied in two Brazilian habitats, Caatinga (Monte Santo, Bahia) and Cerrado (Palmeiras, Bahia and Luiz Antônio, São Paulo). Nests were excavated in the ground and did not tend to be aggregated together at the two sites, but at Palmeiras, nests were in a large aggregation. Nest architecture consists of a single unbranched tunnel, sloping to vertical, which leads to a linear series of four cells, placed from 8 to $26 \mathrm{~cm}$ in depth. Cells are urn-shaped with a rounded base, and their cell caps have a central hollow process, as in other Centridini. Nest architecture of $C$. aenea was compared to other species of Centris Fabricius, 1804. Provisions are composed of a pollen mass covered by a thin liquid layer on which the egg is placed. Females were observed gathering oil on Mcvaughia bahiana W.R. Anderson flowers from October to March in the Caatinga, and on Byrsonima intermedia A.Juss. as well as other Malpighiaceae species from August to December in the Cerrado. Pollen is gathered by buzzing flowers of Solanaceae, Caesalpiniaceae, Malpighiaceae, and Ochnaceae. Several nectar sources were recorded. There is indirect evidence that Mesoplia sp. parasitizes nests of $C$. aenea in the Cerrado.
\end{abstract}

KEY WORDS. Caatinga, Cerrado, floral oils, nesting behavior, solitary bees.

Centris (Centris) species are ground-nesting bees that excavate their nests principally into horizontal surfaces (VINSON \& FRANKIE 1977, 1988, 1991, VINSON et al. 1987), although occasionally into vertical surfaces such as earth banks (Coville et al. 1983). Nests of eight species of this subgenus have been described: Centris aethyctera Snelling, 1974 (VINSON \& FrankIE 1977, 1991), Centris segregata Crawford, 1906 (Coville et al. 1983), Centris decolorata Lepeletier, 1841 and Centris fasciata Smith, 1854 (RAW 1984), Centris flavofasciata Friese, 1899 (VInson et al. 1987), Centris leprieuri (Spinola, 1841) (GotTSBERgER et al. 1988), Centris flavifrons (Fabricius, 1775), and Centris aethiocesta Snelling, 1984 (VINSON \& FRANKIE 1988). Observations concerning the nests of other South American ground-nesting species belonging to other Centris subgenera have been made by Claude-Joseph (1926), Vesey-Fitzgerald (1939), Janvier (1955), Callan (1977), Camillo et al. (1993), Laroca et al. (1993) and Chiappa \& Toro (1994).

Centris (Centris) aenea Lepeletier, 1841 is a medium-sized bee species. Its geographic distribution ranges from the Guianas to São Paulo, Brazil (Moure 1969), and it is present in several habitats in Brazil, mainly in areas of open vegetation such as Caatinga (Martins 1994, Zanella 2000), Cerrado (Silveira \& Campos 1995), and Restingas (beach areas) (Silva \& Martins 1999, Viana \& Alves-Dos-Santos 2002), as well as secondary growth forest (CuRE et al. 1992). Nesting biology data for this species has not been published previously. Michener \& LANGe (1958) cited the occurrence of nest aggregation on flat ground in Porto Atlântida (Mato Grosso, Brazil). In this work a description of the nests and the nesting behavior of $C$. aenea is presented.

\section{MATERIAL AND METHODS}

\section{Study sites}

Nests of $C$. aenea were studied in the municipal districts of Monte Santo $\left(10^{\circ} 19^{\prime} 29^{\prime \prime}\right.$; $\left.3^{\circ} 9^{\circ} 13^{\prime} 59^{\prime \prime} \mathrm{W}\right)$ and Palmeiras $\left(12^{\circ} 27^{\prime} 38^{\prime \prime}\right.$; $\left.41^{\circ} 31^{\prime} 08^{\prime \prime} \mathrm{W}\right)$ in the Bahia State, and in the Estação Ecológica de Jataí (EEJ) at Luiz Antônio (São Paulo State, 2133'$37^{\prime} \mathrm{S} ; 47^{\circ} 45^{\prime}-51^{\prime} \mathrm{W}$ ). The climate at Monte Santo is Tropical Semiarid, Bsh according to the Köppen classification, with an average annual temperature of $23.6^{\circ} \mathrm{C}$. The average annual precipitation is $657 \mathrm{~mm}$ (range: 295 to $1466 \mathrm{~mm} /$ year) and the rainy periods are from November to December, and March to May (BAHIA 1994). The vegetation is predominantly open shrubby Caatinga, with clumps of arboreal Caatinga in the vicinity. At Palmeiras, the study site is covered by Cerrado and the climate is Tropical Semi-humid, Aw in the Köppen classification, with 
an average annual temperature of $23.2^{\circ} \mathrm{C}$. The annual precipitation ranges from 1000 to $1200 \mathrm{~mm} /$ year and the rainy season is from November to March or April (BAHIA 1978).

The climate at the EEJ is Aw according to the Köppen classification. Temperatures are highest in the rainy season (November to April), and lowest from May to October (PIREs et al. 2000). The vegetation is mainly semi-deciduous forest, with several different physiognomies of Cerrado (predominately Cerradão) in different stages of regeneration.

\section{Nesting activity}

Nesting activity of $C$. aenea was observed between October and December, 2000, at Monte Santo. Nesting females were not encountered at this site during inspection trips made in February, March, and May, 2000, nor during January and June, 2001. At Palmeiras, a nest aggregation was found on December, 2002 , when a great number of females were nesting. At the EEJ site, nests were accompanied from August to November, in both 1998 and 1999. Nesting females were not seen at any other time during biweekly visits to this site throughout 1998 and 1999.

Twenty-one nests were opened (five from Luiz Antônio, six from Monte Santo and 10 from Palmeiras), but just two of them had been completed by the females. Cells and tunnels were measured and described. Twelve cells were maintained in the laboratory until the adults emerged. At Monte Santo, the activities of two nesting females were followed between 05:00 and 18:00 h for two consecutive days, on October, 2002.

Voucher specimens of bees studied in EEJ were deposited in the RPSP collection, and plant vouchers at the SPFR herbarium, both in Faculdade de Ciências e Letras de Ribeirão Preto, São Paulo.

\section{RESULTS}

\section{Nesting sites}

Centris aenea excavated its nests into flat surfaces, mainly clay or other hard soils (Fig.1). They were not observed nesting on sandy soils. At Monte Santo, nests $(n=6)$ were established near pollen (Chamaecrista pascuorum (Benth.) Irwin \& Barneby) and oil furnishing plants (Mcvaughia bahiana W.R. Anderson), being excavated near the roots of shrubs and herbaceous plants that shaded the area. The ground at nesting sites was covered by fallen leaves and twigs, although one nest was established in an area without any leaf litter. The nests were not aggregated, being separated one from another by from 2 to $22 \mathrm{~m}$. At the EEJ site, nests were usually established on bare and sunny ground, although in a few cases in areas covered by fallen leaves. Distances between nests varied, but they were never densely aggregated. Differently, the nests at Palmeiras were disposed in dense aggregation covering circa $340 \mathrm{~m}^{2}$ $(85 \times 40 \mathrm{~m})$, and their entrances were as close as 3 to $5 \mathrm{~cm}$ in some places. There were circa 40 nests $/ \mathrm{m}^{2}$ in the most dense nesting sites, but nests were not equally distributed throughout the nesting area. The nests were excavated in the ground covered by grasses, but also in soil without vegetation.

\section{Nest construction behavior}

Females flew approximately $10 \mathrm{~cm}$ above the ground while selecting a nesting site. Occasionally they landed and excavated the soil for a few seconds, and then flew on. This process was repeated several times until the female selected a site and started actual nest excavation. At Monte Santo, nesting sites were commonly shaded by branches of the shrub $M$. bahiana. Earth removed from the tunnel under excavation accumulated beside the entrance, forming a small mound. Later, the female scattered the soil in a single direction with her hind legs, while moving quickly backwards several times (Fig. 1).

The first working day was occupied in the excavation of the main tunnel and in the construction of the first cell, and the female spent most of her time within the nest. Excavation activity was interspersed with quick trips (six to seven minutes), sometimes in order to retrieve nectar from Melochia tomentosa L. (Sterculiaceae) at the Monte Santo site, or from Memora peregrina (Miers.) Sandwith (Bignoniaceae) at the EEJ site. When cell construction was concluded, the female made two or three trips to gather oily substances for coating the inner cell walls. In the late afternoon the female sealed the nest entrance with soil, small pebbles, and twigs and spent the night inside the nest.

\section{Nest Architecture}

The nest entrances were circular to oval, and ranged from 9 to $15 \mathrm{~mm}$ in diameter. Entrances were easily visible due to the presence of a small soil mound nearby. In the Caatinga, however, nest entrances could be hidden under pieces of wood, fallen leaves, or twigs. Immediately below the entrance, an unbranched and unlined tunnel (8-12 $\mathrm{mm}$ in diameter) descended at a $30^{\circ}$ to $45^{\circ}$ angle for 3 to $10 \mathrm{~cm}$. The tunnel would then angle directly downward for an additional 6 to $20 \mathrm{~cm}$, until reaching the area where the cells were constructed (Fig. 2 ). One nest at the Monte Santo site differed significantly in its architecture, taking the form of a horizontal tunnel only 2 to $3 \mathrm{~cm}$ below the surface, and most nest tunnels in Palmeiras were almost totally vertical below the entrance.

Cells were aligned vertically, one after another, at depths 8 to $26 \mathrm{~cm}$. The shaft containing the cells was not perfectly vertical, however, as the bottom of each individual cell was slightly inclined in relation to the cap of the cell immediately below it. Consecutive cells were separated by layers of soil 2 to $7 \mathrm{~mm}$ thick. Two of the five nests examined at the EEJ site had been completed, and both had a series of four consecutive cells. The nests examined at the Monte Santo site had from two to three cells, and those at Palmeiras had one to four cells, although none of the nests had been completed.

The cell itself is urn-shaped and has a rounded base (Fig. 4). The outer surface is rough due to the adherence of soil particles, while the inner surface is smooth and has a dark, smooth coating. The maximum outer widths of the cells ranged from 12 to $16 \mathrm{~mm}(\mathrm{n}=20)$, and their lengths ranged from 18 to $26 \mathrm{~mm}(\mathrm{n}=21)$; the cell walls were 0.5 to $1 \mathrm{~mm}$ thin. Each cell was sealed with a cell cap. These caps have a hollow central projection, 2 to $3.6 \mathrm{~mm}$ high, that is folded over on itself. The cell caps are slightly recessed, and cell walls thus form a $1 \mathrm{~mm}$ high lip around it.

The bottom of each cell was stocked with nutrient provisions, to a depth of approximately $8 \mathrm{~mm}$. The nutrient provisions appeared to be solid at the bottom, with a transparent liquid layer on the surface. One cylindrical and slightly curved egg was placed on the liquid surface.

\section{Cell provisioning}

The provisioning of two cells was observed at the Monte 

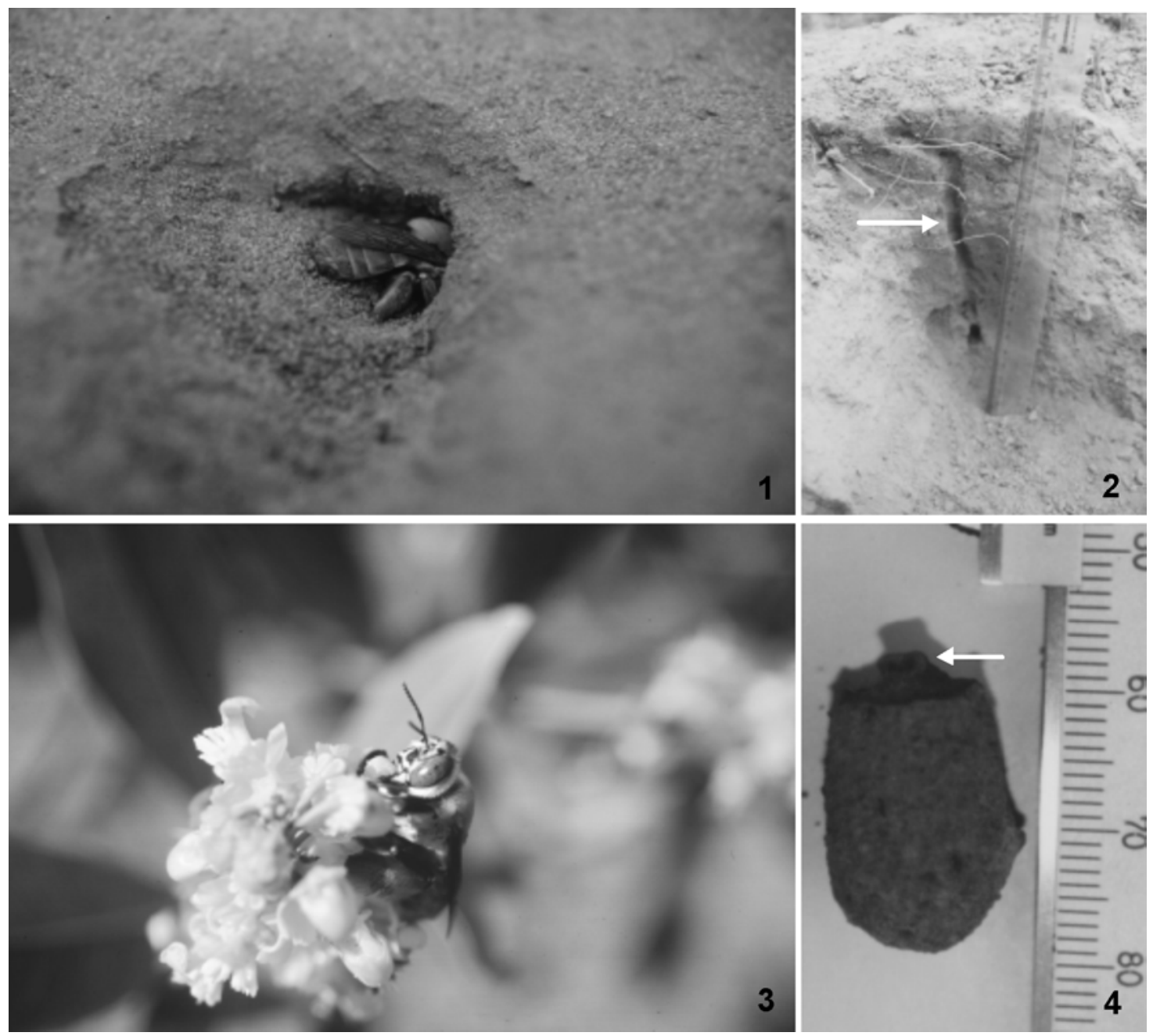

Figures 1-4. (1) Female excavating a nest burrow. (2) C. aenea nest architecture showing the main tunnel (arrow) that leads to the vertically orientated cells. (3) Centris aenea female gathering oil from a Byrsonima intermedia flower. Its mandibles are holding the flag petal while the flower anthers contact the thorax ventrally. (4) C. aenea cell. Arrow indicates the central process.

Santo site. The female began to provision the first cell in the morning, immediately after completing its construction. After the first cell had been provisioned and sealed, the female constructed and provisioned a second cell during the same day. The provisioning of the first cell required about $3.5 \mathrm{~h}$, while the second required $3.0 \mathrm{~h}$. In both cases, five trips were necessary to gather pollen and then three additional trips were made to gather oil. It was impossible to establish if the females also gathered nectar to add to the provisions. Females spent 16 to 42 minutes $(n=5)$ collecting oil before returning to the nest. Trips to provision the first cell with pollen required an average of $33.6 \pm 6.4 \mathrm{~min}$ (33 to 42 minutes), and then $20.8 \pm 2.8 \mathrm{~min}$ utes (17 to 22 minutes) $(n=5)$ to provision the second cell. The time spent inside the nest after delivering a pollen load was approximately three minutes.
Activities outside of the nest started between 05:00 and 06:30 $\mathrm{h}$ (sunrise) in the morning, and the bees could be observed visiting flowers until nearly sunset $(17: 30 \mathrm{~h})$. At the Monte Santo site, bees were occasionally observed visiting flowers 10 to 15 minutes before sunrise, and then approximately 15 minutes after sunset.

\section{Floral visits and seasonality}

The floral resources used by C. aenea at the Monte Santo and Luiz Antônio sites are listed in table I. At the EEJ site females were recorded visiting three different species of Malpighiaceae flowers (Tab. I, Fig. 3) during the reproductive period from August to December. Mcvaughia bahiana was the only source of floral oils observed at Monte Santo and at Palmeiras females visited Byrsonima sericea D.C. flowers for oil. 
Table I. Plant species visited by Centris aenea in cerrado (E.E. Jataí, Luiz Antônio, São Paulo and Palmeiras, Bahia) and caatinga (Monte Santo, Bahia) sites. Collected rewards: $(\mathrm{N})$ nectar, $(\mathrm{P})$ pollen, $(\mathrm{O})$ floral oils.

\begin{tabular}{|c|c|c|c|c|c|}
\hline Plant families & Plant species & Rewards & EE Jataí & Palmeiras & Monte Santo \\
\hline Bignoniaceae & Memora peregrina (Miers.) Sandwith & $\mathrm{N}$ & $\bullet$ & & \\
\hline \multirow[t]{2}{*}{ Caesalpiniaceae } & Caesalpinia pyramidalis Mart ex Tul & $\mathrm{N}$ & & & $\bullet$ \\
\hline & Chamaecrista pascuorum (Benth.) Irwin \& Barneby & $\mathrm{P}$ & & & • \\
\hline \multirow[t]{2}{*}{ Fabaceae } & Zornia brasiliensis Vog. & $\mathrm{N}$ & & & $\bullet$ \\
\hline & Chaetocalyx scandens (L.) var. pubescens (DC.) Rudd & $\mathrm{N}$ & & & • \\
\hline Flacourtiaceae & Xylosma cf. ciliatifolium (Clos.) Eichl & $\mathrm{N}$ & & & • \\
\hline \multirow[t]{5}{*}{ Malpighiaceae } & Mcvaughia bahiana W.R. Anderson & $\mathrm{O}$ & & & • \\
\hline & Byrsonima sericea D.C. & $\mathrm{P}, \mathrm{O}$ & & - & \\
\hline & Byrsonima intermedia A.Juss. & $\mathrm{P}, \mathrm{O}$ & $\bullet$ & & \\
\hline & Banisteriopsis pubipetala (A.Juss.) Cuatrecasas & $\mathrm{O}$ & - & & \\
\hline & Heteropterys byrsonimifolia A.Juss. & $\mathrm{O}$ & - & & \\
\hline \multirow[t]{2}{*}{ Mimosaceae } & Mimosa arenosa (Willd.) Poir. & $\mathrm{N}$ & & & - \\
\hline & Chloroleucon foliolosum (Benth.) G.P. Lewis & N & & & • \\
\hline Ochnaceae & Ouratea spectabilis (Mart.) Engl & $\mathrm{P}$ & ○ & & \\
\hline Oxalidaceae & Oxalis psoralioides H.B.K. & $\mathrm{N}$ & & & - \\
\hline Solanaceae & Solanum lycocarpum A.Saint-Hil & $P$ & - & & \\
\hline Sterculiaceae & Melochia tomentosa L. & N & & & $\bullet$ \\
\hline Vochysiaceae & Qualea multiflora Mart. & $\mathrm{N}$ & ○ & & \\
\hline
\end{tabular}

Females were observed nesting at Monte Santo in October. It is possible, however, that these bees may be active for longer periods in this area, since they were seen visiting oilflowers in October, February and March, while in May 2000, and June 2001, females were not observed foraging.

\section{Immatures}

We observed in the laboratory the emergence of adult bees from three cells derived from two completed nests. These nests were established on August 27, 1998 at the beginning of C. aenea nesting activity in the Cerrado. The first nest contained four cells, and two females emerged from them on November 15 and 18, 1998 (at 80 and then 83 days after nest establishment, respectively). The second nest also had four cells although only a single male emerged (from the third cell) on October 30, 1998 (64 days after nest establishment). A male pupa was observed in the first cell of another nest (established on October 1, 1998); its body was larger than that expected for a normal male, indicating that it was probably a beta male. Beta males were observed patrolling nesting sites in the Cerrado from late October until mid November.

\section{Parasites}

Mesoplia sp. females were observed making quick flights near the ground at nesting sites in the Cerrado (Luiz Antônio and Palmeiras). When these parasite bees found a C. aenea nest while the host female was absent, they would enter inside and remain there for some minutes. Nonetheless, this represents only indirect evidence of nest parasitism by Mesoplia sp., as no parasite offspring emerged from cells maintained in laboratory. Parasites were not recorded near $C$. aenea nests at the Caatinga site. Species of Mutillidae (Hymenoptera) and Meloidae (Coleoptera), probably enemies of $C$. aenea, were seen on the ground in the nest aggregation at Palmeiras.

\section{DISCUSSION}

Centris aenea nests share a number of features with other ground-nesting Centris species, such as: shallow nests, uncoated tunnel walls, cell caps with central hollow tubes, and urnshaped cells made from aggregated soil particles and having a granular outer surface but a smooth inner surface coated by an oily substance (ALCOCK et al. 1976, VINSON \& FRANKIE 1977, 1988, Coville et al. 1983, Vinson et al. 1987, Rozen \& Buchmann 1990, LAROCA et al. 1993, CAMillo et al. 1993). Vertical and linear cell alignment also occur in other ground-nesting species belonging to the subgenus Centris [C. aethyctera (VINSON \& FrankIE 1977) and C. segregata (Coville et al. 1983)] and the subgenus Paracentris Cameron, 1903 [Centris austrani Vachal, 1904 (JANVIER 1955)], in cavity-nesting species of the subgenera Heterocentris Cockerell, 1899 [Centris vittata Lepeletier, 1841 (PEREIRA et al. 1999), Centris analis (Fabricius, 1804) (Jesus \& Garófalo 2000)], as well as in bees of the subgenus Ptilotopus Klug, 1810 that nest in termite mounds [Centris sponsa (Smith, 1854) (LARoca et al. 1993), Centris derasa (Lepeletier, 1841) (Vesey-FitzGerald 1939; Bennett 1964), Centris scopipes (Friese, 1899) (Gaglianone 2001)].

Revista Brasileira de Zoologia 20 (4): 601-606, dezembro 2003 
Species of the subgenus Centris show a basic pattern of nest architecture consisting of a single unbranched tunnel (although it may be branched or bifurcated at the terminal end), ending in one or more cells. The nests of $C$. aenea were similar to those of $C$. aethyctera as described by VInSON \& FrankiE (1977), although the latter demonstrated variations in nest architecture depending on the substrate (VINSON \& Frankie 1991). In other species, variations on the basic pattern of nest architecture were observed: C. flavifrons (VINSON \& FRANKIE 1988) and C. flavofasciata (VINSON et al. 1987) excavate blind lateral burrows; C. aethiocesta constructs two or three unbranched tunnels originating from a single shared entrance (VINSON \& FRANKIE 1988); C. segregata constructs either a single unbranched tunnel, or two to three tunnels that branch just below the entrance (Coville et al. 1983); while $C$. decolorata nests are composed of a main tunnel that branches into three shorter ramifications, each one ending in a single cell (RaW 1984).

Nest construction in shaded sites that are protected against direct sun light probably represents an important strategy for species that make shallow nests, such as C. aenea. High temperatures (up to $45^{\circ} \mathrm{C}$ on hot summer days in the Caatinga) can be harmful to larval development (Frankie et al. 1993).

The construction of nests near pollen and oil sources reduces the amount of time and energy spent in gathering food resources. The proximity between nests and floral resources can be very important in the Caatinga environment where some host plants (such as M. bahiana) show a clustered distribution, often with a wide separation between clusters. At the Cerrado sites, however, plant oil sources were scattered over the entire area, and nests distribution seems to be not directly associated with plant localization at Luiz Antônio, although the nests were concentrated in an area with high density of Byrsonima sericea trees at Palmeiras.

The list of floral resources used by C. aenea demonstrates the wide spectrum of host plants utilized within the study areas. Malpighiaceae species belonging to distantly related genera such as Byrsonima, Banisteriopsis, Heteropterys, and Mcvaughia (CAMERON et al. 2001; DAvis et al. 2001) serve as oil sources for this bee species. Additional plants from at least four different families serve as pollen sources. In other diverse Brazilian habitats, Centris aenea visits the flowers of several additional families (Aguiar et al. in preparation). This generalist behavior could be expected in light of the wide geographical distribution of this bee species, which occurs in different ecosystems with very distinctive climatic characteristics and floristic compositions.

In comparison to other species that construct singlecelled nests, Centris aenea has reduced the time and effort spent to produce each cell by constructing shallow nests with several cells. However, multicelled nests can be more susceptible to parasite attacks. In the Caatinga, nests entrances were cryptic, increasing protection against cleptoparasitic bee species. Although parasites were not seen around the nests studied in the Caatinga area, Mesoplia sp. (Hymenoptera, Apidae, Ericrocidini) probably attacks C. aenea nests in areas of Cerrado. Bees of the genus Mesoplia Lepeletier, 1841 parasite the nests of other Centris (Morato et al. 1999) and Epicharis Klug, 1807 (GAGLianone 2002) species.

Some characteristics of $C$. aenea biology, such as the wide spectrum of host plants utilized, multi-celled nests, and a relatively long reproductive period, would seem to contribute to fact that this is one of the most abundant solitary bee species in some areas of Caatinga and Cerrado. The different climatic conditions could be affecting some strategies of the nesting biology of $C$. aenea differently in the two ecosystems. The localization of the nests in shaded areas and in the proximity to the oil sources probably are important to this species in a very hot and sunny ambient like the caatinga, where the floral resources can be scarce, or sometimes clumped. The nesting periods seem to be different in the Caatinga and Cerrado, beginning first (August) in the Cerrado, when the Caatinga at Monte Santo is in the critic dry period and the start of $C$. aenea nesting period coincides with the rainy season.

\section{ACKNOWLEDGEMENTS}

The authors are grateful to Sebastião Oliveira for help during fieldwork at E.E. Jataí and G.F. Almeida and C.L. Queiroz at Monte Santo. We are also indebted to Dra. Maria Candida Mamede for identifying the Malpighiaceae species of EEJ, to Luciano Paganucci de Queiroz and Flávio França for identifying the plants from Monte Santo. We also thank Dr. Carlos Alberto Garófalo for suggestions on the manuscript.

\section{REFERENCES}

Alcock, J.; C.E. Jones \& S.L. Buchmann. 1976. The nesting behavior of three species of Centris bees (Hymenoptera: Anthophoridae). Journal of the Kansas Entomological Society, Kansas, 49 (4): 469-474.

BAHIA. 1978. Atlas Climatológico do Estado da Bahia; O Clima como recurso natural básico à organização do espaço geográfico. Salvador, SEPLANTEC, 191p.

BAHIA. 1994. Informações básicas dos municípios bahianos: Região Nordeste. Salvador, Centro de Estatística e Informação, vol. 11 (II), 955p.

BenNetr, F.D. 1964. Notes on the nesting site of Centris derasa (Hymenoptera: Apoidea). The Pan-Pacific Entomologist, San Francisco, 40 (2): 125-128.

Callan, E.C. 1977. Observations on Centris rufosuffusa Cockerell (Hymenoptera: Anthophoridae) and its parasites. Journal of Natural History, London, 11: 127-135.

Cameron, K.M.; M.W. Chase; W.R. Anderson \& H.G. Hills. 2001. Molecular systematics of Malpighiaceae: evidence from plastid rbcL and matK sequences. American Journal of Botany, Columbus, 88: 1847-1862.

Camillo, E.; C.A. Garófalo \& J.C. Serrano. 1993. Hábitos de nidificação de Melitoma segmentaria, Centris collaris, Centris fuscata e Paratetrapedia gigantea (Hymenoptera, Anthophoridae). Revista Brasileira de Entomologia, São Paulo, 37 (1): 145-156.

Chiappa, E. \& H. Toro. 1994. Comportamiento reproductivo de Centris mixta tamarugalis (Hymenoptera: Anthophoridae). II Parte: nidification y estados immaduros. Revista Chilena de Entomologia, Santiago de Chile, 21: 99-115.

Claude-Joseph, F. 1926. Recherches biologique sur les Hyménoptères du Chili. Annales des Sciences Naturelles, Zoologie et Biologie Animale, Paris, 9: 113-268.

Coville, R.E.; G.W. Frankie \& S.B. Vinson. 1983. Nests of Centris segregata (Hymenoptera: Anthophoridae) with a review of the nesting habits of the genus. Journal of the Kansas Entomological Society, Kansas, 56 (2): 109-122. 
Cure, J.R.; M. Thiengo; F.A. Silveira \& L.B. Rocha. 1992. Levantamento de abelhas silvestres na Zona da Mata de Minas Gerais. III - Mata secundária na região de Viçosa (Hymenoptera, Apoidea). Revista Brasileira de Zoologia, Curitiba, 9 (3-4): 223-239.

Davis, C.C.; W.R. Anderson \& M.J. Donoghue. 2001. Phylogeny of Malpighiaceae: evidence from cloroplast $n d h F$ and trnl-F nucleotide sequences. American Journal of Botany, Columbus, 88: 1830-1846.

Frankie, G.W.; L. Newstrom; S.B. Vinson \& J.F. Barthell.1993. Nesting habitat preferences of selected Centris bee species in Costa Rican dry forest. Biotropica, Washington, 25 (3): 322-333.

Gaglianone, M.C. 2001. Nidificação e forrageamento de Centris (Ptilotopus) scopipes Friese (Hymenoptera, Apidae). Revista Brasileira de Zoologia, Curitiba, 18 (Supl. 1): 107-117.

. 2002. Uma análise comparativa da nidificação das espécies de Epicharis. Ribeirão Preto, Anais do Encontro sobre Abelhas 5, p. 47-52.

Gottsberger, G.; J.M.F. Camargo \& I. Silberbauer-Gottsberger. 1988. A bee pollinated tropical community: the beach dune vegetation of Ilha de São Luis, Maranhão, Brazil. Botanische Jahrbücher für Systematik, Pflanzengeschichte und Pflanzengeographie, Stuttgart, 109 (4): 469-500

JANVIER, H. 1955. Le nid et la nidification chez quelques abeilles des Andes tropicales. Annales des Sciences Naturelles, Zoologie et Biologie Animale, Paris, 17 (11): 311-349.

Jesus, B.M.V. \& C.A. Garófalo. 2000. Nesting behaviour of Centris (Heterocentris) analis (Fabricius) in southeastern Brazil (Hymenoptera, Apidae, Centridini). Apidologie, Avignon, 31: 503-515.

Laroca, S.; D.T. Reynaud dos Santos \& D.L. Schwartz Filho. 1993. Observations on the nesting biology of three Brazilian centridini bees: Melanocentris dorsata (Lepeletier 1841), Ptilotopus sponsa (Smith 1854) and Epicharitides obscura (Friese, 1899) (Hymenoptera: Anthophoridae). Tropical Zoology, Firenze, 6: 153-163.

Martins, C.F. 1994. Comunidade de abelhas (Hym.,Apoidea) da caatinga e do cerrado com elementos de campo rupestre do estado da Bahia, Brasil. Revista Nordestina de Biologia, João Pessoa, 9 (2): 225-257.

Michener, C.D. \& R.B. LANGe. 1958. Observation on the ethology of Neotropical Anthophorine bees (Hymenoptera: Apoidea). University of Kansas Science Bulletin, Kansas, 39 (3): 6996.

Morato, E.; M.V.B. Garcia \& L.A.O. Campos. 1999. Biologia de Centris Fabricius (Hymenoptera, Anthophoridae, Centridini) em matas contínuas e fragmentos na Amazônia Central. Revista Brasileira de Zoologia, Curitiba, 16 (4): 1213-1222.

Moure, J.S. 1969. Notas sobre algumas espécies de Centris da Guiana (Hym., Apoidea). Anais da Academia Brasileira de Ciências, Rio de Janeiro, 41 (1): 113-123.

Pereira, M.; C.A. Garófalo; E. Camillo \& J.C. Serrano. 1999.
Nesting biology of Centris (Hemisiella) vittata Lepeletier in southeastern Brazil (Hymenoptera, Apidae, Centridini). Apidologie, Avignon, 30: 327-338.

Pires, A.M.Z.C.R.; J.E. SAntos \& J.S.R. Pires. 2000. Caracterização e diagnóstico ambiental de uma unidade da paisagem. Estudo de caso: Estação Ecológica de Jataí e Estação Experimental de Luiz Antônio, p. 1-26. In: J.E. SAnTos \& J.S.R. Pires (Eds). Estação Ecológica de Jataí, vol. 1. Estudos Integrados em Ecossistemas. São Carlos, Editora Rima, 346p.

RaW, A. 1984. The nesting biology of nine species of Jamaican bees (Hymenoptera). Revista Brasileira de Entomologia, São Paulo, 28 (4): 497-506.

Rozen, J.G. \& S.L. Buchmann. 1990. Nesting biology of immature stages of bees Centris caesalpiniae, C. pallida, and the cleptoparasite Ericrocis lata (Hymenoptera: Apoidea, Anthophoridae). American Museum Novitates, New York, 2985: 1-30.

Silva, M.C.M. \& C.F. Martins. 1999. Flora apícola e relações tróficas de abelhas (Hymenoptera: Apoidea) em uma área de restinga (Praia de Intermares, Cabedelo-PB, Brasil). Principia, João Pessoa, 7: 40-51.

Silveira, F.A. \& M.J.O. Campos. 1995. A melissofauna de Corumbataí (SP) e Paraopeba (MG) e uma análise da biogeografia das abelhas do cerrado brasileiro (Hymenoptera, Apoidea). Revista Brasileira de Entomologia, São Paulo, 39: 371-401.

Vesey-FitzGerald, D. 1939. Observations on bees (Hym.: Apoidea) in Trinidad, B.W.I., Proceedings of the Royal Entomological Society of London, ser. A, London, 14: 107-110.

VIANA, B.F. \& Alves-Dos-SANTOS, I. 2002. Bee diversity of the coastal sand dunes of Brazil, p. 135-153. In: P.G. Kevan \& V.L. IMPEratriz-Fonseca, (Eds.) Pollinating bees: the conservation link between agriculture and nature. Brasília, Ministério do Meio Ambiente, 313p.

Vinson, S.B. \& G.W. Frankie. 1977. Nests of Centris aethyctera (Hymenoptera: Anthophoridae) in dry forest of Costa Rica. Journal of the Kansas Entomological Society, Kansas, 50: 301-311.

. 1988. A comparative study of the ground nests of Centris flavifrons and Centris aethiocesta (Hymenoptera: Anthophoridae). Entomologia Experimentalis et Applicata, Dordrecht, 49: 181-187.

. 1991. Nest variability in Centris aethyctera (Hymenoptera: Anthophoridae) in response to nesting site conditions. Journal of the Kansas Entomological Society, Kansas, 64 (2): 156-162.

Vinson, S.B.; G.W. Frankie \& R.E. Coville. 1987. Nesting habits of Centris flavofasciata Friese (Hymenoptera: Apoidea: Anthophoridae) in Costa Rica. Journal of the Kansas Entomological Society, Kansas, 60 (2): 249-263.

Zanella, F.C.V. 2000. The bees of the Caatinga (Hymenoptera, Apoidea, Apiformes): a species list and comparative notes regarding their distribution. Apidologie, Avignon, 31: 579592.

Received in 13.Il.2003; accepted in 15.X.2003. 